\title{
Seed Quality Evaluation of Senegalia polyphylla (DC.) Britton \& Rose
}

\author{
Patricia Gibbert $^{1}$ (D), Michele Fernanda Bortolini² (D), \\ Daiana Karoline Kaiser ${ }^{1}$ (D), Evelin Maria Muller $^{3}$ (D), Francine Gusatto ${ }^{2}$ \\ ${ }^{1}$ Departamento de Ciências Agrárias, Universidade Estadual do Oeste do Paraná - Unioeste, \\ Marechal Cândido Rondon/PR, Brasil \\ ${ }^{2}$ Pontifícia Universidade Católica do Paraná - PUCPR, Escola de Saúde e Biociências, Toledo/PR, Brasil \\ ${ }^{3}$ Universidade Estadual do Oeste do Paraná, Departamento de Ciências Ambientais, Cascavel/PR, Brasil
}

\begin{abstract}
The aim of this study was to evaluate the quality of Senegalia polyphylla seeds from different trees by X-ray (XR) and electric conductivity (EC) tests. Seeds from three different trees were used. The seeds were classified through radiography in: full, malformed, with small damage and empty, and were used in the germination test. For the EC test, the best volume of water (50 and $75 \mathrm{~mL}$ ) was initially tested at $25^{\circ} \mathrm{C}$, and subsequently, the different soaking times $(12,24,48,72,96$ and 120 hours) using the best volume of water. Concomitantly, the germination test was performed. Tree I presented a higher percentage of full seeds in XR, higher percentage of germination and fewer leachates in the EC; tree III, however, was the opposite. The tests showed to be efficient for the quality evaluation of Senegalia polyphylla seeds, differentiating the trees.
\end{abstract}

Keywords: $\mathrm{x}$-ray, electrical conductivity, forest seeds. 


\section{INTRODUCTION}

Senegalia polyphylla (DC.) Britton \& Rose (former Acacia polyphylla) (INCT, 1939), belonging to the family Fabaceae, is popularly known in Brazil as unha de gato. The plant, occurring from the Amazon region up to Paraná, is classified as a pioneer indicated for projects of recovery of degraded areas, for beekeeping and breeding of native bees, woodworking purposes, landscaping, when in bloom, and urban greening, besides possessing medicinal potential (Carvalho, 2008).

The growing demand for seeds of native forest species, through production and conservation programs, has generated the need to develop technologies for evaluating the quality of these seeds (Carvalho et al., 2009) to make sure that they will originate healthy plants, since obtaining and maintaining high physiological quality of a seed lot is a critical step in the production of seedlings (Muxfeldt et al., 2012).

Since unha de gato is a native forest species, as well as several others, it does not present much information about the physiology and analysis of its seeds; in this way, it is sought to develop and perfect rapid and reliable tests that offer the characterization of the potential and physiological quality of the seeds for sowing and storage purposes (Figliolia et al., 1993). Therefore, different tests have been used.

The evaluation of the internal morphology of seeds is essential both for the characterization of poorly studied species and for the improvement of the quality of seed lots, since the information about the existence of defective and empty seeds is desirable as it may influence the results of germination. The analysis of images for evaluating the internal morphology of seeds, besides not damaging the seeds and making it possible to examine their structure, relating it to other tests contributes to the consistency of information, since the procedures can be reproduced without human interference (Gomes, 2010).

Thus, the possibility of using the image analysis technique is promising, since the seed can be examined individually in enlarged images, indicating in detail the damaged area, its location and the extent of damage (Nunes et al., 2014).

The X-ray test, besides presenting fast results, is not destructive. This technique consists in the absorption of X-rays by the seed tissues (Carvalho et al., 2009), allowing the visualization of the position and shape of the damage that occur in the embryonic axis (Amaral et al., 2011), as well as the seed as a whole.

According to Abreu et al. (2011), the degradation of the cell membranes system is the first stage of the seed deterioration process, so the tests best suited for evaluating subtle differences in vigor between lots are those that evaluate the structure of membranes, such as the electrical conductivity test.

The electrical conductivity test is also important due to its objectivity and speed, in addition to the ease of execution, without major expenses (Krzyzanowski et al., 1999). Besides being a good indicator of vigor, it is related to the initial events of the seed deterioration sequence, such as the degradation of cell membranes and the reduction of respiratory and biosynthetic activities (Carvalho et al., 2009). The test evaluates the seed quality in an indirect way, as it informs the amount of leachate in the seed imbibition solution (Mendes et al., 2010).

The electrical conductivity test is based on the principle that, with the deterioration process, there is the leaching of the cellular constituents of the seeds soaked in water, as a result of the loss of integrity of the cellular membrane systems; thus, low conductivity means high physiological quality of the seed, and high conductivity suggests its lower vigor (Gonzales et al., 2009).

The physiological quality of seeds can be influenced by the different variations in the conditions that seeds undergo when still in the mother plant, and these may highlight certain aspects of their genetic composition, which otherwise would not manifest (Botezelli et al., 2000); also, according to Ignácio (2013), it can be linked to the conditions of seeds' conservation before their use.

In this way, the objective of this study was to evaluate the physical and physiological quality of Senegalia polyphylla seeds from three trees by X-ray and electrical conductivity tests.

\section{MATERIAL AND METHODS}

Unha de gato fruits were collected in May 2014 from three trees (MI, MII and MIII) distant more than 500 meters from each other, located in the western region of Paraná. After the harvest, the pulp from the fruits was removed and the seeds were dried at room 
temperature, packed in polyethylene bottles and stored in a refrigerator with temperature of $9 \pm 3{ }^{\circ} \mathrm{C}$.

The weight of a thousand seeds was determined using eight replicates of 100 seeds weighed in an analytical balance. The water content was determined at the time of installation of each test, using four replicates of $5 \mathrm{~g}$ of seeds placed in aluminum containers of known weight and oven dried at $105 \pm 3{ }^{\circ} \mathrm{C}$, for $17 \pm 1$ hours (Brasil, 2009).

When performing the X-ray test, the seeds were stored for 8 months. To obtain the radiographs, the Faxitron X-ray MX-20 DC-12 device was used, coupled to the computer core 2 Duo and the MultiSync LCD1990SX monitor. The definition of the best intensity and time of exposure of the seeds was determined automatically by the equipment, with the seeds positioned $28.6 \mathrm{~cm}$ away from de X-ray emission site, and the intensity of $26 \mathrm{kv}$, sufficient to diagnose the seed structures. The time of exposure, measured automatically, varied from 7 to 9 seconds, according to the thickness of the seeds.

Eight replicates of 25 seeds were analyzed for each tree, which were placed on transparent double-sided tape adhered on a projection transparency.

From the radiographs the seeds were classified into four categories, according to the internal morphology: full, malformed, with small damage (less than $50 \%$ of the embryo damaged) and empty (more than $50 \%$ of the embryo damaged).

After the radiographs were taken, the seeds were placed in individual containers previously numbered so that the seed could later be correctly evaluated in the germination test. The seeds of the germination test were disinfested with sodium hypochlorite $2 \%$ for five minutes and then sowed in plastic boxes in substrate vermiculite. The plastic boxes were conditioned in BOD incubator at $25^{\circ} \mathrm{C}$ with a 12 -hour photoperiod (Araújo et al., 2003). The plastic boxes' lids were numbered in order to locate each seed in the germination test and compare with the $\mathrm{X}$-ray generated by the X-ray test.

The evaluation of germination was performed daily, considering germinated the seed that had the aerial part emerged (hypocotyl and cotyledons). Concomitantly, the average germination speed and the formation of normal seedlings were evaluated, taking into account the emerged aerial part (hypocotyl and cotyledons and the emergence of the first pair of leaflets) (Brasil, 2009). Results were expressed as percentage of germination and normal seedlings and mean germination speed calculated according to Labouriau (1983).

When the test for the adequacy of water volume for the electrical conductivity test was carried out, the seeds from tree III were freshly harvested. When comparing the trees by the electrical conductivity test, seeds from the trees I, II and III were stored for 11 months.

Preliminary tests were carried out to determine the adequate volume of water, using four replicates of 50 seeds from tree III for each volume of water and imbibition time. The seeds were weighed on analytical balance and arranged in plastic cups, which were kept closed in BOD incubator at $25^{\circ} \mathrm{C}$, with volumes of deionized water of 50 and $75 \mathrm{~mL}$ and with different soaking times (12, 24, 48, 72, 96 and 120 hours).

After each soaking time, the imbibition solution was read using QUIMIS conductivity meter $(0.00$ to $19.999 \mu \mathrm{S})$. From the reading result the pure water reading (without seeds) was subtracted and the result was divided by the weight of the subsample, expressed in $\mu S . \mathrm{cm}^{-1} \cdot \mathrm{g}^{-1}$ per seed, according to Krzyzanowski et al. (1999).

Having the adequate water volume to perform the test $(50 \mathrm{~mL})$, a new electrical conductivity test was performed, with seeds from the three trees. Four replicates of 50 seeds were used for each tree and imbibition time (24, 48, 72, 92 and 120 hours). The procedures and evaluations were performed as described above. Simultaneously, the germination test and evaluations were carried out, according to the methodology already described.

The data for the evaluation of the categories obtained by the X-ray test were analyzed in a $3 \times 3$ factorial scheme (categories $\times$ trees), with eight replicates of 25 seeds. For the germination test performed with the seeds of each category, the data were analyzed in a $3 \times 3$ factorial scheme (categories $\times$ trees), with eight replicates of 25 seeds.

The statistical analysis of the preliminary test for the electrical conductivity was in a factorial scheme $6 \times 2$ (imbibition times $\times$ volumes of water) with four replicates of 50 seeds.

For the final test of electrical conductivity, the statistical analysis was in a factorial scheme $5 \times 3$ (imbibition times $\times$ trees), with four replicates of 50 seeds. For the germination test performed along with the electrical conductivity test, the statistical 
analysis was in a completely randomized design with eight replicates of 25 seeds for each tree.

For all the tests, the normal distribution of the residues was evaluated. The variances of the treatments were tested for homogeneity by the Bartlett test. Those that were homogeneous were submitted to analysis of variance (test F), and their means were compared by the Tukey test at the level of 1 and $5 \%$ of probability.

\section{RESULTS AND DISCUSSION}

At the moment of the X-ray test, seeds from the trees I, II and III had $14.3 \%, 13.5 \%$ and $15.2 \%$ of water content, respectively. For the preliminary electrical conductivity test, seeds from tree III had $13.4 \%$ of water content. Seeds submitted to the final test of electrical conductivity presented $15.6 \%, 16 \%$, and $15.9 \%$ of water content for the trees I, II and III, respectively. For the weight of one thousand seeds trees I, II and III presented 78.6, 83.7 and $59.1 \mathrm{~g}$, respectively.

According to Carvalho et al. (2009), the water content of the seeds in the X-ray test influences the optical density, that is, the lower the water content of the seeds, the greater the differentiation of the internal structures of the seeds visualized in the radiographs. Therefore, the low water content of the seeds permitted a better visualization and differentiation of the structures.

Figure 1 shows the radiograph of seeds from the four categories, and in Table 1 the percentages of each $\mathrm{X}$-ray category for each tree can be observed.

According to Table 1, tree I presented the highest percentage of full seeds, differing statistically from the other trees. It can be observed that tree III has the highest percentages of malformed seeds and with small damage, differing statistically from the other trees. Tree III was the only one to present empty seeds; for this reason, this category was not submitted to statistical analysis.

Among the categories, the one with the highest percentage of seeds was that of full seeds, which differed statistically from the categories of malformed seeds and with small damage, which had smaller percentages. The pattern of seeds percentage for each category found in the present study was observed by other authors, such as Albuquerque \& Guimarães (2008) with sucupira-preta seeds (Bowdichia virgilioides) and Carvalho et al. (2009) with species of Lauraceae.

For the germination test with the seeds submitted to the X-ray test, it was observed that in all trees the percentage for the full category was higher, differing significantly from the other categories. The categories of malformed seeds and with small damage did not differ significantly between them (Table 2).

Among the trees, the percentage of germination for the full seed category did not present a significant difference. For the categories of malformed seeds and with small damage, tree III presented a higher percentage (Table 2), since this tree had a higher percentage of seeds in these categories (Table 1), making the mean value higher.

For the average germination speed, it was observed that, for tree I, the category of full seeds was the one with the highest speed ( 0.21 seedlings/day), which significantly differed from the malformed categories

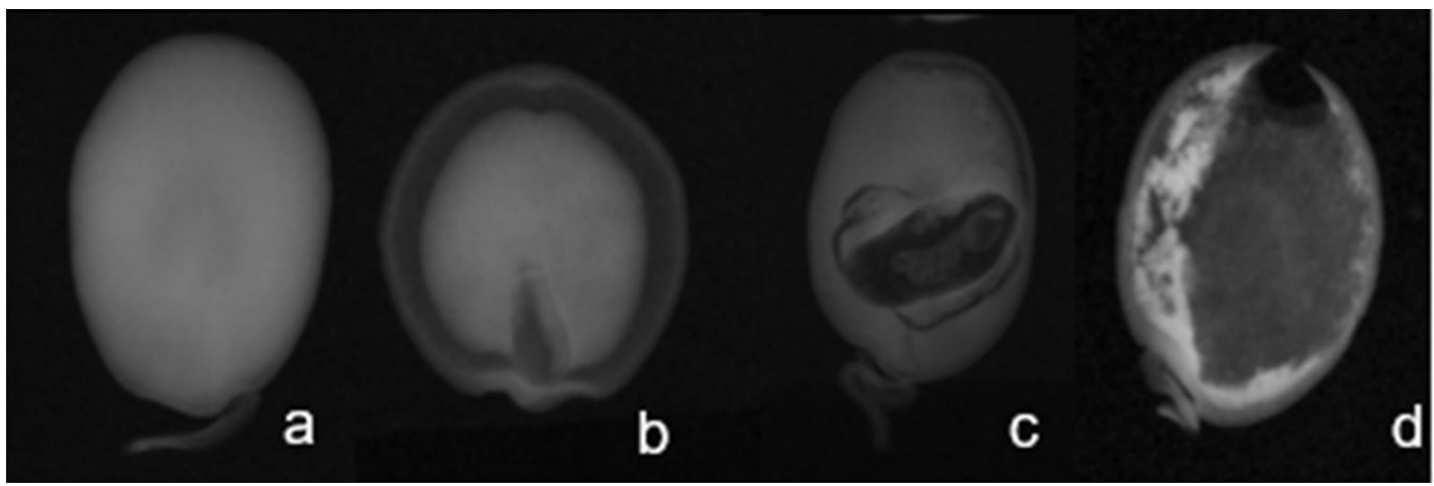

Figure 1. Radiograph of the seed categories of Senegalia polyphylla: (a) full seed, (b) malformed, (c) with small damage, and (d) empty. 
Table 1. Percentage of seeds of Senegalia polyphylla according to the classification by X-ray test, for each tree.

\begin{tabular}{|ccccc|}
\hline Categories & Tree I & Tree II & Tree III & Mean \\
\hline Full & $990.5 \mathrm{aA}$ & $80.5 \mathrm{aB}$ & $51.5 \mathrm{aC}$ & 74.2 \\
\hline Malformed & $9 \mathrm{bC}$ & $18 \mathrm{bB}$ & $25.5 \mathrm{bA}$ & 17.5 \\
\hline Small damage & $0.5 \mathrm{cB}$ & $1.5 \mathrm{cB}$ & $11.5 \mathrm{cA}$ & 4.5 \\
\hline Empty & - & - & 11.5 & \\
\hline Mean & 33.3 & 33.3 & 29.5 \\
\hline CV $\%$ & 14.33 & & \\
\hline
\end{tabular}

Means followed by the same letter (lowercase in the column and uppercase in the row) do not differ by Tukey test $(p>0.01)$.

${ }^{*}$ Not included in the statistical analysis. CV: coefficient of variation.

Table 2. Percentage and average germination speed, and percentage of normal Senegalia polyphylla seedlings for each category of the X-ray test and tree.

\begin{tabular}{|c|c|c|c|c|}
\hline Germination/category (\%) & Tree I & Tree II & Tree III & Mean \\
\hline Full & $90.3 \mathrm{aA}$ & $87 \mathrm{aA}$ & $88.4 \mathrm{aA}$ & 88.5 \\
\hline Malformed & $12.5 \mathrm{bB}$ & $22.5 \mathrm{bB}$ & $59.8 \mathrm{bA}$ & 31.6 \\
\hline Small damage & $12.5 \mathrm{bB}$ & $22.5 \mathrm{bB}$ & $49.2 \mathrm{bA}$ & 28.9 \\
\hline Mean & 38.4 & 44.8 & 65.8 & \\
\hline $\mathrm{CV} \%$ & 27.76 & & & \\
\hline $\begin{array}{l}\text { Average speed of germination } \\
\text { (Seedlings/day)/category }\end{array}$ & Tree I & Tree II & Tree III & Mean \\
\hline Full & $0.21 \mathrm{aA}$ & $0.17 \mathrm{aAB}$ & $0.12 \mathrm{aB}$ & 0.16 \\
\hline Malformed & $0.09 \mathrm{bA}$ & $0.08 \mathrm{abA}$ & $0.15 \mathrm{aA}$ & 0.12 \\
\hline Small damage & 0.01 & 0.04 & 0.14 & \\
\hline Mean & 0.15 & 0.13 & 0.13 & \\
\hline $\mathrm{CV} \%$ & 19.35 & & & \\
\hline Normal seedling/category (\%) & Tree I & Tree II & Tree III & Mean \\
\hline Full & $96.9 \mathrm{aA}$ & $98.6 \mathrm{aA}$ & $95 \mathrm{aA}$ & 96.8 \\
\hline Malformed & $37.5 \mathrm{bB}$ & $50 \mathrm{bB}$ & $74.5 \mathrm{bA}$ & 54 \\
\hline Small damage & $12.5 \mathrm{cB}$ & $12.5 \mathrm{cB}$ & $56.3 \mathrm{cA}$ & 27.1 \\
\hline Mean & 49 & 53.7 & 75.2 & \\
\hline $\mathrm{CV} \%$ & 8.05 & & & \\
\hline
\end{tabular}

Means followed by the same letter (lowercase in the column and uppercase in the row) do not differ by Tukey test ( $p>0.01$ ). Empty categories not included in the statistical analysis (null values). ${ }^{*}$ Not included in the statistical analysis. CV: coefficient of variation.

and with small damage. For trees II and III there was no statistical difference between the categories (Table 2).

Comparing the trees, the average germination speed for the full seeds was higher in trees I and II, with tree I differing from trees II and III, and tree II not differing statistically from tree III. Considering the category of malformed seeds, tree III differed significantly from tree II. Seeds with small damage presented higher speed in tree III, differing from the other trees.

For the percentage of normal seedlings, the seeds classified as full obtained the highest percentages, followed by seeds with small damage and malformed, differing significantly from each other (Table 2).
When comparing the trees, it was observed that for the category of full seeds, the trees did not differ from each other. For the malformed and with small damage, the highest percentage was for tree III, differing statistically from the other trees (Table 2).

Tree III presented the highest amount of malformed seeds and with small damage, and the lowest amount of full seeds (Table 1). On the other hand, normal seedling formation was higher in the categories malformed and with small damage (Table 2). This is due to the fact that tree III had the highest amount of seeds in these categories; however, normal seedlings of tree III were thinner and smaller when compared to the normal seedlings of trees I and II. 
For the same species, there are individual variations among trees because of environmental influences during seed development and genetic variability. The high genetic variability due to the relatively wild stage, without domestication, has been pointed out as the cause of the great variation in the germinative behavior of seeds of Brazilian native forest species (Santos et al., 2009); for instance, in the present study it was observed that the three trees differ from each other in the number of seeds per category (Table 1). Also, they differed in the percentage of germination and normal seedlings and in the average speed of germination (Table 2), although the seeds belonged to the same species and were in similar conditions in the germination.

It was observed that although most of the seeds were characterized as full (Table 1), not all of them emerged (Table 2), which may be due to invisible infections caused by fungi. Gomes et al. (2014) report that the $\mathrm{X}$-ray test detects the existence or not of formed tissues, but it does not necessarily establish a direct relationship with the physiological processes of the seed, so the seed may be full, but not germinate and give rise to a normal seedling. According to Pupim et al. (2008), morphologically perfect seeds, identified by the X-ray test, may be dormant and originate normal or abnormal seedlings or may even be dead.

Albuquerque \& Guimarães (2008) observed in sucupira-preta (Bowdichia virgilioides) seeds that the speed of germination decreased as the damage by insects and fungi increased, a fact observed for trees I and II of the present study; however, the inverse was observed for tree III. Through the X-ray test, it was observed that damage results in the decrease of the reserve tissue of the seeds, and thus, the seeds tend to have less energy for the germination. Furthermore, there is a relation with the location of the damage in the seed, if it is close to the vital region or not, which results in the germination or not of the seed, as well as the formation of the normal seedling.

According to Carvalho et al. (2009), the possibility of damage detection in the seeds allows their disposal, guaranteeing the highest quality of the lot, besides contributing to their conservation in the storage. Muxfeldt et al. (2012) also report that the removal of these seeds prevents the transfer of insects to other seeds.
According to Carvalho et al. (2009), seeds damaged by predators, but not close to embryonic axis, can germinate, which does not occur if the predation is in the embryonic axis. The presence of deteriorated tissues or malformations are limiting factors for the viability and, depending on the affected location, can reduce the vigor, giving rise to weak seedlings, consequently more susceptible to adverse conditions (Nunes et al., 2014).

Regarding the electrical conductivity test to determine the adequate volume of water, it was observed that only in the 12-hour time there was no significant difference between the volumes of water tested. In the other times of conductivity measurement there was a significant difference between the volumes of water, and the amount of $75 \mathrm{~mL}$ showed the lowest readings (Table 3).

Although the amount of $75 \mathrm{~mL}$ presented lower values of conductivity, it was decided to use $50 \mathrm{~mL}$, because according to literature, with a higher amount of water there is a greater dilution of the leachates, in this way, the quantity of $75 \mathrm{~mL}$ exhibits higher dilution compared to the amount of $50 \mathrm{~mL}$, and consequently lower reading of the solution.

When conducting the electrical conductivity test to select the adequate water volume, tree III presented 13.4\% humidity. At the moment of the final test, the seeds from trees I, II and III presented 15.6\%, 16\% and 15.9\% of humidity, respectively. These values are within the standard recommended by Krzyzanowski et al. (1999), between $10 \%$ and $17 \%$, besides having uniformity in the degrees of humidity.

Table 3. Mean values of electrical conductivity $\left(\mu \mathrm{S} . \mathrm{cm}^{-1} \cdot \mathrm{g}^{-1}\right)$ of Senegalia polyphylla seeds with different amounts of water.

\begin{tabular}{cccc} 
& $\mathbf{5 0} \mathbf{~ m L}$ & $\mathbf{7 5} \mathbf{~ m L}$ & Mean \\
\hline 12 hours & $86.69 \mathrm{aA}$ & $52.97 \mathrm{aA}$ & 69.8 \\
\hline 24 hours & $168.68 \mathrm{bB}$ & $110.68 \mathrm{bA}$ & 139.7 \\
\hline 48 hours & $238.39 \mathrm{cB}$ & $192.55 \mathrm{cA}$ & 215.5 \\
\hline 72 hours & $459.96 \mathrm{~dB}$ & $277.10 \mathrm{dA}$ & 368.5 \\
\hline 96 hours & $542.41 \mathrm{eB}$ & $470.88 \mathrm{eA}$ & 506.6 \\
\hline 12 hours & $727.48 \mathrm{fB}$ & $561.67 \mathrm{fA}$ & 644.6 \\
\hline Mean & 370.6 & 277.6 & - \\
\hline CV \% & 8.07 & & \\
\hline
\end{tabular}

Means followed by the same letter (lowercase in the column and uppercase in the row) do not differ by the Tukey test $(\mathrm{P}>0.01)$. CV: coefficient of variation. 
With the increase in the amount of water, it was observed a decrease in the values of electrical conductivity. According to Ataíde et al. (2012) this is due to the fact that there is a greater dilution of the ions in the imbibition solution. Dalanhol et al. (2014) observed that the amount of $50 \mathrm{~mL}$ of water was efficient for differentiation of sublots, in addition to presenting lower coefficient of variation.

Flávio \& Paula (2010) observed that in the highest volume of water there was little difference in the leaching patterns in the initial periods of imbibition, regardless of the number of seeds, and thus recommended the use of $50 \mathrm{~mL}$. In addition, the authors, using seeds of Dyctyoloma vandellianum (tingui-preto), emphasize that if it is desired to obtain fast results, it is necessary to adopt smaller volumes of water, like $50 \mathrm{~mL}$, to conduct the test.

Pereira \& Martins (2012), in studies with cubiu (Solanum sessiliflorum), report that higher volumes of water do not allow the stratification of lots according to the physiological characterization. Gonçalves et al. (2008) recommended volumes of 50 or $75 \mathrm{~mL}$ for Guazuma ulmifolia (mutamba).

It can be noticed that the longer the imbibition period, the higher the electrical conductivity values. Thus, the volume of $50 \mathrm{~mL}$ was adopted for convenience and because of the difficulty of stratification of lots when using larger volumes of water.

As the imbibition time increased, the conductivity reading went higher, differing significantly from each other. The 120-hour time showed the largest readings, and there was no leachate stabilization throughout the test. These results corroborate with those of Gonzales et al. (2009) with Albizia hassleri (farinha-seca),
Dalanhol et al. (2014) with Bowdichia virgilioides (sucupira-preta), Dutra et al. (2007) with Senna siameal (cassia de sião), among others.

There is no stabilization of the leachates due to the non-saturation of the imbibition water, that is, the seeds had not leached enough to stabilize the leachate between the seed and the solution, a fact also found by Dalanhol et al. (2014).

In Table 4 it was observed, among the trees, that tree I has the smallest amount of leachate when compared to the other trees in all the imbibition times, except for the 72-hour time, in which it does not differ from tree II. There was also no stabilization of leachate.

In Table 5, it was observed that the percentage of germination was higher in tree I, which did not differ statistically from tree III. For the average speed of germination there was no significant difference among the trees. For the percentage of normal seedlings, tree I again stood out, differing statistically from the other trees.

It was observed in Table 4 that tree I stands out from the others with less leachate, demonstrating that these seeds have high quality, corroborating with the germination and normal seedling data, which were higher in tree I (Table 5).

According to Krzyzanowski et al. (1999), conductivity can be affected by some factors, such as humidity, mechanical or insect damage, seed size, genotypes, seed water content, among others.

In the present study, the 24-hour period was efficient for the classification of the physiological quality of the trees. Dalanhol et al. (2014), with seeds of Bowdichia virgilioides (sucupira-preta), also obtained lots differentiation with 24 hours. Marques et al. (2002),

Table 4. Mean electrical conductivity values $\left(\mu \mathrm{S} . \mathrm{cm}^{-1} \cdot \mathrm{g}^{-1}\right)$ of the final test of seeds from different trees of Senegalia polyphylla.

\begin{tabular}{ccccc} 
& Tree I & Tree II & Tree III & Mean \\
\hline 24 hours & $101.78 \mathrm{aA}$ & $219.79 \mathrm{aB}$ & $203.72 \mathrm{aB}$ & 175.0 \\
\hline 48 hours & $254.57 \mathrm{bA}$ & $328.32 \mathrm{bB}$ & $377.18 \mathrm{bB}$ & 320.0 \\
\hline 72 hours & $363.45 \mathrm{cdA}$ & $402.64 \mathrm{bA}$ & $497.93 \mathrm{cB}$ & 421.3 \\
\hline 96 hours & $342.80 \mathrm{cA}$ & $547.46 \mathrm{cB}$ & $558.55 \mathrm{cB}$ & 482.9 \\
\hline 120 hors & $431.26 \mathrm{dA}$ & $537.20 \mathrm{cB}$ & $654.39 \mathrm{dC}$ & 541.0 \\
\hline Mean & 298.8 & 407.1 & 458.4 & \\
\hline CV $\%$ & 10.5 & & & \\
\hline
\end{tabular}

Means followed by the same letter (lowercase in the column and uppercase in the row) do not differ by Tukey test $(\mathrm{P}>0.01)$. $\mathrm{CV}$ : coefficient of variation. 
Table 5. Percentage of germination and normal seedlings of Senegalia polyphylla for each tree of the electrical conductivity test.

\begin{tabular}{lcc|} 
& $\begin{array}{c}\text { Percentage of } \\
\text { germination }\end{array}$ & $\begin{array}{c}\text { Normal seedling } \\
(\%)^{* *}\end{array}$ \\
\hline Tree I & $77.5 \mathrm{a}$ & $75.5 \mathrm{a}$ \\
\hline Tree II & $58 \mathrm{~b}$ & $56 \mathrm{~b}$ \\
Tree III & $66 \mathrm{ab}$ & $58.5 \mathrm{~b}$ \\
Mean & 66 & 62 \\
\hline CV\% & 18 & 19.23 \\
\hline
\end{tabular}

Means followed by the same letter in the column did not differ significantly $\left({ }^{*} \mathrm{p}>0.05\right),\left({ }^{* *} \mathrm{p}>0.01\right)$. CV: coefficient of variation.

however, needed 30 hours with seeds of Dalbergia nigra (jacarandá da Bahia).

Cherobini et al. (2008), with seeds of Cedrela fissilis (cedro) and Sesbania virgata (sesbania), evidenced a relationship between germination and electrical conductivity tests. This was also observed in this study, and tree I presented the lowest values of electrical conductivity, and higher percentage of germination (Tables 4 and 5, respectively).

Correlating the X-ray and electrical conductivity tests, it was observed that tree III presented lower physiological quality, with the highest percentage of seeds of lower quality and greater amount of leachate in the electrical conductivity test. The greatest release of the exudates in the electrical conductivity test may be due to the partial or total attack of insects and larvae on the seeds, as well as deterioration of the seeds, which are detected in the X-ray test. Tree I released less leachate in the electrical conductivity test and detected a lower percentage of seeds with damage by the X-ray test.

\section{CONCLUSION}

The X-ray test is efficient for the physical evaluation of Senegalia polyphylla seeds when they are positioned at $28.6 \mathrm{~cm}$ from the source of X-ray emission, with intensity of $26 \mathrm{kv}$ and time between 7 and 9 seconds, the latter being automatically measured by the equipment.

The electrical conductivity test is efficient for evaluating the physiological quality of Senegalia polyphylla seeds, being recommended the use of 50 seeds in $50 \mathrm{~mL}$ of water for 24 hours.

\section{ACKNOWLEDGEMENTS}

À PUCPR pela concessão da bolsa para auxílio do desenvolvimento do presente estudo, e a todos, desde a professora/orientadora até os colegas que auxiliaram.

Agradeço ao prof. Dr. Francisco Guilhien Gomes Junior por ceder espaço para a realização do teste e raio $\mathrm{X}$, bem como a todo conhecimento por ele transmitido.

\section{SUBMISSION STATUS}

Received: 23 mar., 2017

Accepted: 27 mar., 2018

\section{CORRESPONDENCE TO}

\section{Patricia Gibbert}

Departamento de Ciências Agrárias, Universidade Estadual do Oeste do Paraná UNIOESTE, Marechal Cândido Rondon, Paraná, Brasil, CEP: 85923-000, Toledo, PR, Brasil e-mail: patriciagibbertt@gmail.com

\section{FINANCIAL SUPPORT}

Nothing to declare.

\section{REFERENCES}

Abreu LAS, Carvalho MLM, Pinto CAG, Kataoka VY. Teste de condutividade elétrica na avaliação de sementes de girassol armazenadas sob diferentes temperaturas. Revista Brasileira de Sementes 2011; 33(4): 635-642. http:// dx.doi.org/10.1590/S0101-31222011000400005.

Albuquerque KS, Guimarães RM. Avaliação da qualidade de sementes de sucupira-preta (Bowdichia virgilioides Kunth.) pelo teste de raios x. Ciência e Agrotecnologia 2008; 32(6): 1713-1718. http://dx.doi.org/10.1590/S141370542008000600005

Amaral JB, Martins L, Forti VA, Cícero SM, Marcos J Fo. Teste de raios x para avaliação do potencial fisiológico de sementes de ipê-roxo. Revista Brasileira de Sementes 2011; 33(4): 601-607. http://dx.doi.org/10.1590/S010131222011000400001 .

Araújo JC No, Aguiar IB, Ferreira VM. Efeito da temperatura e da luz na germinação de sementes de Acacia polyphylla DC. Revista Brasileira de Botanica. Brazilian Journal of Botany 2003; 29(2): 249-256. http://dx.doi.org/10.1590/ S0100-84042003000200013. 
Ataíde GM, Flôres AV, Borges EEL, Resende RT. Adequação da metodologia do teste de condutividade elétrica para sementes de Pterogyne nitens Tull. Agrária 2012; 7(04): 635-640. http://dx.doi.org/10.5039/agraria.v7i4a1688.

Botezelli L, Davive AC, Malavasi MM. Características dos frutos e sementes de quatro procedências de Dipteryx alata Vogel (Baru). Cerne 2000; 6(1): 9-18.

Brasil. Ministério da Agricultura e Reforma Agrária. Regras para análise de sementes. Brasília: SNDA/DNDV/ CLAV; 2009.

Carvalho LR, Carvalho MLM, Davide AC. Utilização do teste de raios $\mathrm{x}$ na avaliação da qualidade de sementes de espécies florestais de Lauraceae. Revista Brasileira de Sementes 2009; 3(4): 57-66. http://dx.doi.org/10.1590/ S0101-31222009000400007.

Carvalho PER. Espécies arbóreas brasileiras. 3. ed. Brasília: Embrapa; 2008.

Cherobini EAI, Muniz MFB, Blume E. Avaliação da qualidade de sementes e mudas de cedro. Ciência Florestal 2008; 18(1): 65-73. http://dx.doi.org/10.5902/19805098511.

Dalanhol SJ, Rezende EH, Abreu DCA, Nogueira AC. Teste de condutividade elétrica em sementes de Bowdichia virgilioides Kunth. Revista Floresta e Ambiente 2014; 21(1): 69-77. http://dx.doi.org/10.4322/floram.2014.013.

Dutra AS, Medeiros S Fo, Diniz FO. Teste de condutividade elétrica em sementes de Senna siamea (Lam.) H.S. Irwin \& Barneby. Revista Ciência Agronômica 2007; 38(3): 280-285.

Figliolia MB, Oliveira EC, Piña-Rodrigues FCM. Análise de sementes. In: Aguiar IB, Piña-Rodrigues FCM, Figliolia MB coord. Sementes florestais tropicais. Brasília: ABRATES; 1993. p. 137-174

Flávio JJP, Paula RC. Testes de envelhecimento acelerado e de condutividade elétrica em sementes de Dictyoloma vandellianum A. Juss. Scientia Forestalis 2010; 38(87): 391-399.

Gomes FG Jr. Aplicação da análise de imagens para avaliação da morfologia interna de sementes. Informativo ABRATES 2010; 20(3): 33-51.

Gomes KBP, Martins RCC, Martins IS, Gomes FG Jr. Avaliação da morfologia interna de sementes de Terminalia argentea (Combretaceae) pelo teste de raios X. Revista Ciência Agronômica 2014; 45(4): 752-759. http://dx.doi. org/10.1590/S1806-66902014000400013.

Gonçalves EP, Paula RC, Desmatlê MESP. Testes de vigor em sementes de Guazuma ulmifolia Lam. Revista de Ciências Agrárias (Belém) 2008; 29(2): 265-276.
Gonzales JLS, Paula RC, Valeri SV. Teste de condutividade elétrica em sementes de Albizia hassleri (Chodat) Burkart. Fabaceae - Mimosoideae. Revista Árvore 2009; 33(4): 625 634. http://dx.doi.org/10.1590/S0100-67622009000400005.

Ignácio, VL. Germinação e conservação de sementes de Balfourodendron riedelianum (Engler) Engler [tese]. Marechal Cândido Rondon: Universidade Estadual do Oeste do Paraná; 2013.

Institutos Nacionais de Ciência e Tecnologia - INCT. Herbário Virtual da Flora e dos Fungos. Senegalia polyphylla [online]. Recife: INCT; 1939 [citado em 2014 Out 1]. Disponível em: http://www.splink.org.br/index.

Krzyzanowski FC, Vieira RD, França JB No. Vigor de sementes: conceitos e testes. Londrina: ABRATES; 1999.

Labouriau LG. A germinação de sementes. Washington: Organização dos Estados Americanos; 1983.

Marques MA, Paula RC, Rodrigues TJD. Adequação do teste de condutividade elétrica para determinar a qualidade fisiológica de sementes de Jacarandá da Bahia (Dalbergia nigra (VELL.) Fr. All. Ex Benth.). Revista Brasileira de Sementes 2002; 24(1): 271-278. http://dx.doi.org/10.1590/ S0101-31222002000100038.

Mendes RC, Dias DCFS, Pareira MD, Dias L. Testes de vigor para avaliação do potencial fisiológico de sementes de mamona (Ricinus communis L.). Ciência e Agrotecnologia 2010; 34(1): 114-120. http://dx.doi.org/10.1590/S141370542010000100015 .

Muxfeldt RE, Faria JMR, Tonetti OAO, Silva EAA. Utilização do teste de raios $\mathrm{X}$ na avaliação dos efeitos da dessecação e infestação em diásporos de canela-batalha Cryptocarya aschersoniana (Lauraceae). Cerne 2012; 18(4): 657-666. http://dx.doi.org/10.1590/S0104-77602012000400016.

Nunes RTC, Souza UO, Morais OM, Lourenço CMS. Análise de imagens na avaliação da qualidade fisiológica de sementes. Revista Verde de Agroecologia e Desenvolvimento Sustentável 2014; 9(5): 84-90.

Pereira MD, Martins S Fo. Adequação da metodologia do teste de condutividade elétrica para sementes de cubiu (Solanum sessiliflorum Dunal). Agrarian 2012; 5(16): 93-98.

Pupim TL, Novembre AD, Carvalho MLM, Cicero SM. Adequação do teste de raios x para avaliação de qualidade de sementes de embaúba (Cecropia pachystachya Trec.). Revista Brasileira de Sementes 2008; 30(2): 28-32. http:// dx.doi.org/10.1590/S0101-31222008000200004.

Santos FS, Paula RC, Sabonaro DZ, Valadares J. Biometria e qualidade fisiológica de sementes de diferentes matrizes de Tabebuia chrysotricha (Mart. Ex A. DC.) Standl. Scientia Forestalis 2009; 37(82): 163-173. 